\title{
APPENDIX III. CARBON AND CARBONATE ANALYSES, LEG 25
}

\author{
W. A. Girdley, Mesa College, Grand Junction, Colorado
}

\section{INTRODUCTION}

During Leg 25, a total of 196 samples was taken from eight holes, and each sample was analyzed for the amount of acid-soluble and insoluble carbon as a basis for reporting the amount of "calcium carbonate" and "organic" carbon in the sediments. These data are given in Table 1, and pertinent results are discussed in the appropriate site report chapters.

Carbon determinations were made by utilizing a LECO (Laboratory Equipment Corporation) 70 second carbon analyzer. The full procedure for carbon-carbonate determination is given in detail in Appendix III, Volume IV, Initial Reports of the Deep Sea Drilling Project (1970).

\section{GENERAL RESULTS}

\section{Carbonate}

High calcium carbonate content reflects the abundant biogenous constituents of most cores. In general, the more abundant biogenous content comprises the younger portions of cores and indicates a more shallow sea floor position during which the bottom was above or at the carbonate compensation depth. For the most part, these biogenous sediments constitute typical oozes. Although locally developed and of little significance volumetrically, other carbonate consists of irregular calcium carbonate fragments and silt-size rhombs, rhodocrosite rhombs, and thin beds of limestone composed of calcium carbonate silt.

\section{Carbon}

The amount of organic carbon in most cores is apparently insignificant based on average values generally given for most oceanic sediments; but two sites, Sites 241 and 249 , are exceptions, Turekian $(1968$, p. 41$)$ notes that, in general, the organic compound concentration in deep-sea sediments is less than 1 percent, and this is the case for the vast majority of samples tested from Leg 25 . However, in the above exceptions organic concentrations as high as 2 percent were noted. Site 241 , Core 28 , Section 2 contains a massive sand interval which locally contains 2 percent organic carbon. At Site 249, below Core 23, Section 5, cores are characterized by zones of dark silty claystones and volcanic siltstones which contain organic carbon ranging from 1 to 1.7 percent and which average nearly 1.5 percent in the 16 samples tested for organic carbon. These amounts are only slightly less than the 3 to 5 percent reported for the Dead Sea (Turekian, 1968, p. 41) which is well known for its anaerobic bottom environment. Thus, it is interpreted that the intervals at Site 249 which contain an average of 1.7 percent organic carbon represent deposition under similar restricted (euxinic) conditions.

\section{REFERENCE}

Turekian, K. K., 1968. Oceans: Englewood Cliffs, N. J. (Prentice-Hall, Inc.). 